\title{
SOME ADDITIONAL MATERIALS ON THE SPIRIT LAKE MASSACRE.
}

[When the memorial tablet in the Hamilton county courthouse and the monument at Lake Okoboji were respectively erected, materials upon the Spirit Lake massacre and on the various attendant features were extensively published. From time to time thereafter we have received materials adding somewhat to the record. We herewith present contributions on three phases of the subject.

The first is a paper prepared by Prof. O. C. Howe at the time of the dedication of the monument. Professor Howe was one of the party of four who discovered the victims and carried the report back to Fort Dodge.

The second is a communication from Mr. R. A. Smith of the relief expedition, who explains the division of the party in the face of a hazard from which Captain Johnson and Mr. Burkholder lost their lives.

The third is a memorandum of the founder of the Historical Department upon his labors in connection with the commemoration of the service of Hamilton County men on the relief expedition, rather more frankly told than as published in the ANNALS during his life.-EDIToR. 1

THE DISCOVERY OF THE SPIRIT LAKE MASSACRE.

BY ORLANDO C. HOWE.

On the 15th ${ }^{1}$ day of March, 1857, our party, eonsisting of Robert Wheelock, B. F. Parmenter, C. Snyder and O. C. Howe, after a tedious trip of more than three weeks, came in sight of the beautiful lakes in Dickinson County, Iowa. We had been exposed to the storms of that terrible winter and apparently had reached the promised land. The weather in the afternoon had sqftened, the clouds vanished for a time, and the shining sun over these groves seemed like a welcome. Our point of view was from the highlands east of the southern point of the Okoboji groves.

Mr. Wheelock and I had been at the lakes in the preceding fall for a week or more, leaving on the last day of November, 1856. While there, we stayed at the cabin of Joel Howe and selected for a town site a tract near the southwesterly shore

\footnotetext{
'Mr. Smith's article following gives the date as the 16th, and that date corresponds with Mr. Howe's account of each day's happenings until they reached Ft. Dodge.-Ed.
} 


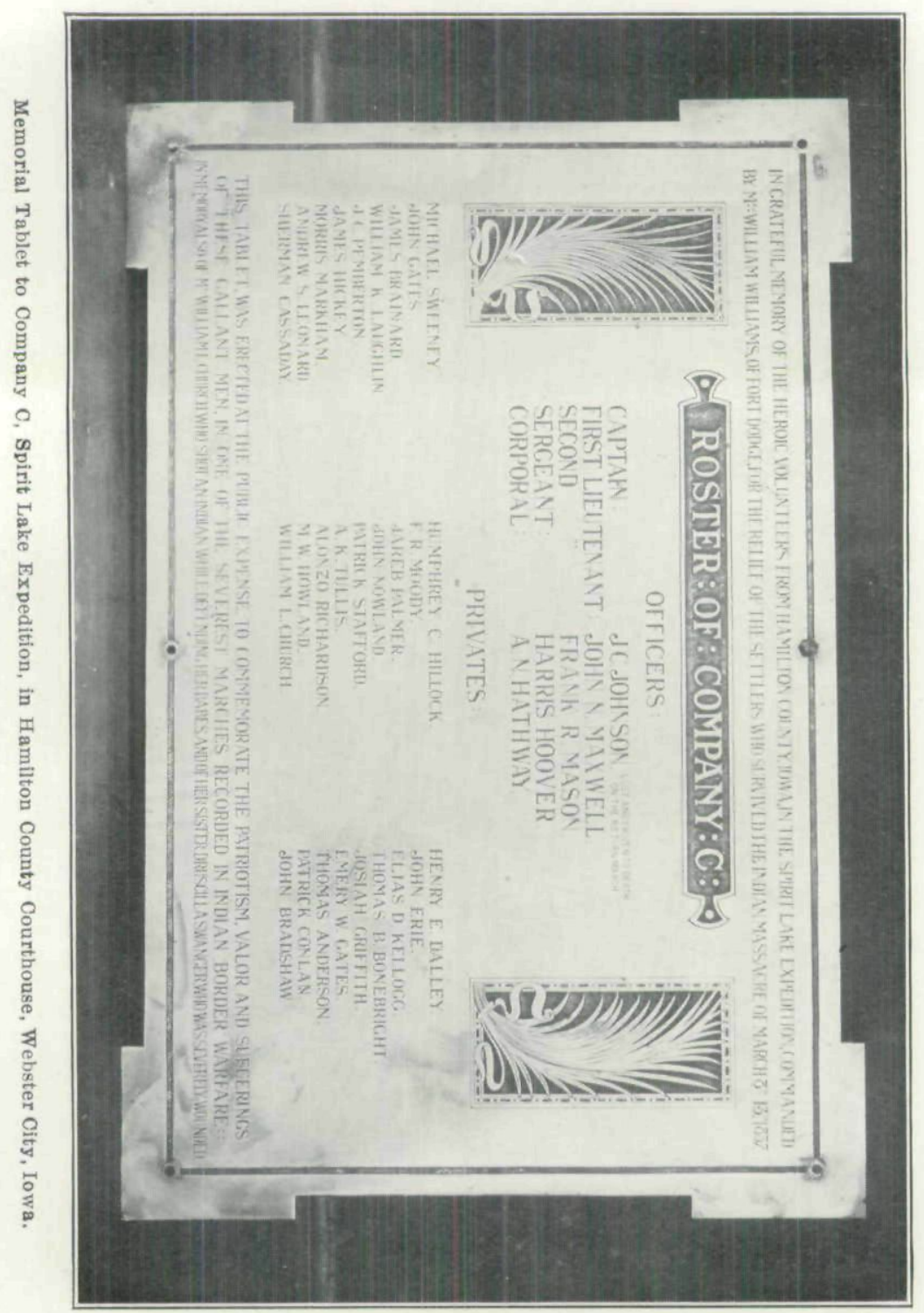


of Spirit Lake and extending south nearly to the present town of Spirit Lake. We examined the country adjacent, and easily found a sufficient number of elaims for a large settlement. While we were there, two Indians eame to Mr. Howe's cabin, one of them morose and silent, while the other, being able to talk English and very friendly, was very playful with the children.

Two days before we left, wishing to know more about the outlines of Spirit Lake, I started in the afternoon to go around the lake on horseback and visit the camp where the Indian said there were about a hundred of his people. I intended, if they wished it, to stay over night, but if they acted so as to give rise to suspicion of their honesty, to go around to Mr. Marble's eabin, the only one then on that lake. On arriving at the camp, my acquaintance of the day before greeted me kindly and I had, by his interpretation, a little talk with his people and was urged to stay in their camp. They pointed out the fact that the snow was falling lightly, admired my horse, as well as myself, and it seemed best for me to make the acquaintance of $\mathrm{Mr}$. Marble even at the risk of staying over night alone in the grove. I was satisfied that my Indian friends had exaggerated their number.

I went on my way, and about eleven o'clock found the eabin and called to Mr. Marble. He sprang out of bed, and hastily insisted that I should come in and stay with them. He said his wife was suspicious of the Indians, which rather amused us. Before I had fallen asleep, other comers were at the door, and we found that two Indians wanted their supper. We gave them supper, and they wanted to stay that night, but Mrs. Marble objected. One of them was a blearedeyed Indian, and his advanced age was security for his peacefulness. Mr. Marble and myself did not like their manner, and especially the way they went out to examine my horse.

When Wheelock and I left the lakes, we expected to return before January and help prepare for my family which would come early in the spring, for we had not at that time even a suspicion of danger. By reason of the storms of that winter, 
our team was the last, so far as we had learned, that left the lakes till after our return.

Our description of the country had induced Messrs. Parmenter and Snyder to join in our enterprise, and now when the whole basin of the lakes appeared before us, they said we had not in any way exaggerated their beauty. Wheelock and I instantly recognized the situation of Howe's house and also Thatcher's.

Our party had, however, received warning that ought to have been heeded. Before we reached the Boone river, Mr. Hewett Ross informed us that there had been trouble in Clay county from Indians, but he had no definite knowledge as to what had occurred. But two old frontiersmen, Messrs. Lane and Ray, had reported in the fall, that there was danger in that county, had left, and were now near Fort Dodge. At Fort Dodge, Major Williams told us more about it, and said there was some danger of trouble. He advised us not to go to the lakes. Three or four miles above Fort Dodge a Mr. Ray met us and inquired where we were going, and being told, he advised us not to go farther, as he was sure there had been trouble in Clay county, and that Spirit Lake was in great danger.

But we obstinately pressed on our way, hearing no news from the lakes till we reached Mr. Carter's on the west fork of the Des Moines river. Mr. Carter informed us that he did not think there was any danger from Indians, but that Inkapaduta was probably in the vicinity and was thought to be one of the bad ones. He told us that one of that band, about sixteen years old, had lived with him a year, and had by some Indian ceremony become a brother of his son who was about the same age. Both Carter and this son were sure that they would be told by this Indian brother of any attack intended to be made on the whites. Mr. Carter had also heard from Clay county later than the other rumor had given as the time of the troubles there. He did not believe there was danger of trouble at the lakes. There had been some dispute between some of the settlers from Minnesota and those from Iowa on account of claims, and it was ru- 
mored that very serious threats had been made, and in his opinion there was more danger from a quarrel between the whites than there was from the Indians.

We learned there also, that a son and son-in-law of Mr. Howe had heard there was danger of the starvation of the people at the lakes, and that they, with hand sleds, had taken provisions across the prairie from north of us. Another man some time in the winter had attempted to go with a team, but could not take any load, and had left his team and load somewhere on the river, returning on foot.

After leaving Fort Dodge, we found no one had been more than twelve miles with a team since we had left in the fall. When we came to where there was no broken path or track, we found it much quicker traveling with our ox teams than with horses. We were compelled by the blizzards to remain at Carter's several days, and from what we had heard of the danger of starvation, we concluded to leave our horses and one load and to take about a ton of provisions on a sleigh, and with two hand sleds and the oxen to start on. Where the snow was soft we were compelled to draw the provisions on our hand sleds to where it was harder, and then driving the oxen in the track we had made, bring up the sleigh that held our load.

When going down in the fall, we had made an arrangement with a Doctor Bidwell to stop at his log house, which he had just put up. He sold us hay that he had in a stack, and on our return trip we were to stay there as long as we wished. After talking with Carter about the best point to leave the river to go to the lakes, we mentioned the arrangement we had made with Bidwell, and he thought that would be the best place for us to leave all the old trails, and strike for the point we wished to reach at the lakes.

We stopped at Bidwell's cabin to recruit ourselves, (twn of us being sick) and to rest our oxen. We heard from a $\mathrm{Mr}$. Reed who lived about two miles from there, that the two men who had left the river on foot, to take provisions to their relatives on hand sleds, had not been heard from for ten days, and it was feared that they had starved. This 
made it necessary for renewed exertion so we started. After two days of hard work and two sleepless nights, we drew near the end of our journey, earrying relief to the starving. Many have felt the joy of saving human life, and no others could have understood our feelings at that time. We shouted, we cheered, we sang, and hurried on, but there was a foreboding and uncertainty which we could hardly understand that soon checked our rejoicing. We feared we were too late and might find them starved, so our efforts were increased.

It soon was apparent that night would overtake us before the end of our journey. Our oxen were tired and could go no faster, and we concluded to leave them at some place near the first timber and with a hand sled load of provisions strike for Howe's house, hoping to be able to carry enough provisions for that part of the settlement for one night at least. After seeing the house, and leaving the team with feed for the night, we traveled some miles and could have been seen by any one anywhere near several of the houses in the settlement. We took with us our only fire arm, a rifle, and soon came in sight of other houses, and proceeded, if possible, faster than before. Mr. Parmenter noticed that while for many days from every house in sight, some one had come to meet us, having seen no one from abroad since winter set in, none here appeared to welcome us. We said little, but that foreboding of trouble and also danger to ourselves was one that cannot be described.

As we hurried nearer a dog was seen, but it soon ran howling into the woods, and in a short time we silently reached a silent house. The beds and elothing were in confusion on the floor and no living being in sight. There was no time for consideration. Immediate action was necessary. Wheelock and I started for Thatcher's place over a mile distant. Parmenter handed us the rifle and said that he and Snyder would make things ready for a fire and wait for our return. On taking the rifle the hammer was found to be broken off and so we had no fire arms whatever.

Wheelock and I each took a hatchet and a large knife and started out. It was after sunset and the sign of the blizzard 
began to cover the sky. There was a beaten track in the snow where there had been travel between the two houses. However, only a few persons had left a track over it for two or three days as there had been a recent snow. A recent moceasin track at last came into view and Wheelock said that it was probably made by Howe who was wearing moccasins in the fall. As we approached nearer Thatcher's we passed the body of an ox recently killed; a small part of the meat was taken away, also a sinew such as the Sioux Indians then used for bow strings.

Upon our arrival at Thatcher's place we saw confusion similar to that at Howe's. Feather beds and pillows had been ripped open and the feathers scattered over the snow. Wheelock said, "That is an Indian habit and everybody here has been killed by the Indians. We will not go into the house, for we know what we shall find there." I said, "We must learn all we can." I then went up to the door and piles of clothing scattered in confusion and the dead bodies of two men met my eyes.

We immediately returned in haste to our party. Parmenter met us and related that he had found a corpse in Howe's house and said that he believed all the inhabitants of the settlement had starved. We told him that there was more than one corpse, and described the situation at Thateher's, stating that we did not believe there was a single white person alive in the settlement.

By this time the threatened blizzard was upon us. We carried in some wood which had been eut, and agreed that the first thing to do was to have supper, as all of our strength and reason were needed. In addition to some coffee and meat we had prepared, we baked some cakes and ate what we could, with little or no talking but much thinking. We found chairs and seats enough for all four, and sat closely around the stove, while the remainder of the floor was nearly covered by clothes lying in heaps. The body they had seen was near the farther end of the cabin. While eating, I noticed a foot nearly under my chair and drew Snyder's attention to it. He was next to me. He looked up, startled, but was instantly composed. 
As soon as we had finished our supper, Snyder said, "Now is the time for a council of war." The storm was howling outside, and at first thought it seemed that all hope had vanished. But as we could again reason calmly, we determined that if it were possible we would be unanimous in our decision as to what we should do. It was suggested that we might examine the bodies already discovered, and the heaps in the room, and arrive at a conclusion as to the means of death. After some consideration we coneluded that the storm would make it impossible to go to the other settlements in the night, and that there was great danger of ourselves being murdered by the Indians, so we decided to postpone the examination of the bodies and make ready to start for somewhere as soon as we were able to see.

It was later suggested that if we found the people had been murdered by the Indians, we should attempt to warn the colony on the Des Moines river; if we found they had starved, we would go with provisions to all the houses about the lake. We, therefore, prepared our sled and put on it the provisions we had brought from the sleigh, except a portion left for any unfortunate wanderer that might ehance to come that way. Wheelock and Snyder stood at the door, while I examined the bodies and noticed the wounds and Parmenter made pencil memoranda. The first was an unknown man twenty-five or thirty years of age, supposed by us to be the son of Joel Howe. He had been killed by a gun shot under the chin, which came out at the top of his head. The next one examined was Sardis Howe, a young woman eighteen years of age, who had been hired by me in the fall to do housework as soon as I came back with my family. She was shot through the breast. Mrs. Howe was under the bed with her skull crushed. Alfred Howe, about fifteen years old and Philetus Howe, about thirteen years old, were shot. The latter had in his hand a piece of iron with which he had made resistance. We did not find $\mathrm{Mr}$. Joel Howe nor a son of his that was missing. Several of the persons had been tortured and horribly mangled. 
By this time, no doubt remained but that there had been an Indian massacre. Our long night's discussion, as we thought, had prepared us to use our reason, yet it was hard to control our anger and awful thirst for revenge. Wheeloek proposed that we take our knives and hatehets, hunt up the murderers, pretend to surrender, and then each one do his best to kill one of them and thus have the satisfaction of doing them justice; as we supposed we were about to die anyway, we might so enrage them as to compel them to kill us without torture. Snyder said that as there was not more than one chance in a thousand of saving our lives by going away, he too would try to avoid torture. I admitted that there was no apparent chance of either Parmenter or myself, in that storm, having the strength to reach the Colony on the river, but suggested that it would be folly to resign ourselves to death without an effort to save the people there. Parmenter agreed, and said that even if there was but one chance in ten thousand, we would die in discharge of a plain duty. All agreeing, we started to return to our team.

We followed the track near the edge of the timber. The storm increased as time passed, occasionally being so dense that we could see but a few yards ahead of us. On the preceding night, Snyder had taken the point of compass from a hill in sight of our oxen, and of the point where Howe's house was, and so we carried the compass to guide us. About a mile from the house, in a lull of the wind, we found that our track ten paces back of us was entirely filled with snow. Advaneing about one hundred yards, we found a plain moceasin track pointing in the direction of a settlement on the river north of the Colony. We waited a moment to aceount for it, but the storm burst again and filled that track. We passed on convinced by this evidence, that the Indians, as was always their custom, were watching and in all probability had seen us as we were coming in with our team.

By following the compass we soon reached the sled, took off the wagon bed, put most of our load in it, left a few light boards, and took with us a sack of flour, some sugar and coffee, sufficient to sustain us a few days, also a bunch of hay, 
some axes, hatchets and knives, blankets and other bedding and started with the cattle eastward to reach the river settlement. We talked little, and endeavored to save all our strength.

At one of our many necessary rests we talked about that moceasin track, and decided that it must have been made by a runner sent by the Indians to some other Indian eamp on the lakes east of the Des Moines river, but upon reflection thought probably, since the track was made by a moccasin smaller than the average that it was the Indian, Joe, going to warn his adopted brother, Carter. Subsequent events, however, convinced us that he was a messenger to another band and raised a strong suspicion that Joe had been sent as a spy, to live with the whites, and was yet acting as such.

We knew that some fuel or shelter from the timber would be necessary to enable us to live through the night, so we started in a direction a little north of a grove that was on the north of us while on our way to the lakes, but after consultation concluded that we would not change our course, but go in the same direction until opposite the timber, and then turn south so as to reach it.

As we traveled, the weather grew colder, and the gusts stronger, but with almost a calm at times. At last we caught sight of the grove and carried out our plan. We went so as to approach it from the south, and at about four o'clock in the afternoon were at its edge. We tried to go in, but found it was impossible on account of the depth and softness of the snow, and we were compelled to camp at the edge. There were many scattered trees about our camp that could be used for fuel, and soon we were hard at work in preparation for the night. It had eeased snowing and the wind lessened. The sun was shining for an hour or more before sunset which cheered us much.

Several of the large oaks were soon felled and the branches made a good windbreak with our sleds turned sideways against them. The bodies of the large trees being placed where the snow was of little depth, we soon had a bright fire built. After sunset the storm came on with renewed strength 
and the cold increased till nearly daybreak. It required all our efforts to keep from freezing. Wheelock and Snyder continued chopping until late in the night, while the others brought the wood to the fire. Several years after this, a person coming to the lakes inquired what settler was fool enough to take a claim in that grove and do nothing but cut down and burn up so large an amount of timber. He could not believe it, when he was told that all the chopping was done by two men in one night.

When sufficient fuel was brought, we ate some of our provisions and used an incredible amount of coffee and sugar. Then we began to talk of our chances and form plans. We called this "a council of war." Our talk now as on the previous night was not wholly solemn and depressing, but oceasional touches of humor enlivened us and at times brought a genuine laugh. But we were conscious that our danger was still great, and the others claimed playfully that Parmenter and I were too sick to live if we had to walk to the Colony, and so ought have no right to vote in the council. All of us agreed that there was nothing to do but start for the river, and so there was nothing further for the council to decide.

At about four o'clock in the morning the wind ceased and the stars came out and we were soon ready to move on. But the cold was intense. At the first break of day we started and when the sun arose the grove was quite a distance behind us. We all walked so that our teams would not tire till we could reach the river bottom where the snow would be so soft they could not travel with the sleigh.

It was to us a long day. The sun shown so brightly upon the snow that it nearly blinded Snyder and myself, and Wheelock was also affected by it. By noon talking ceased and some one would be continually straggling along and the others would eall him back. We had for nearly a month worked harder than ever before, and having been without sleep many nights while on the journey, we were almost completely exhausted. At one time I wandered and soon lost consciousness of things around me. Visions and thoughts beyond material objects, such as cause vague theories and are elements 
of much superstition were before me. I saw myself on the snow, either dead or perishing and heard my wife and her sister, Mrs. Parmenter, trying to learn where they could find the body. I heard long conversations; then hearing my name called, I answered "What is the matter?" and rose from the snow but no one was in sight. My recollection soon returned and Wheelock came over a hill calling to me and I was then fully awakened. My dream went through many hours, but it was only while they were traveling less than fifty yards. They had passed over a knoll and Snyder sat down on the 'sled and fell asleep, and while picking him up Wheelock noticed my absence and hunted me up.

As soon as we started again I proposed that as all of us had had a turn at wandering, one of us be placed on the sleigh and sleep five minutes while all the others walked. I took the first ride and was instantly asleep, and being awakened, was surprised that I had slept only ten minutes. They had doubled the time agreed upon, when they decided it was not cold enough to freeze us. It was not long until each had taken his turn at sleeping several times, from which came so much refreshment and strength as to enable us to be sure of reaching the river safely, and was, I believe, the only thing that could have sustained us.

As the day wore away we were anxious to see the timber, and toward night Parmenter saw it plainly. A few minutes afterwards Snyder could distinguish it. The others were too nearly snow-blind to see any distance. They told us that the timber was a long way off, but we felt strong and thought we could afford to hurry. After several miles, Wheelock was also able to see the timber. Snyder and Parmenter had no knowledge of that part of the river, and we had been anxious to know whether or not we were traveling in the right direction. Wheelock, at first, could not recognize it, for it appeared like two little lines some distance apart. The others said they had noticed that from the first, and we were discouraged again.

Just before sunset we passed over a ridge and my eyesight returned and I could distinetly see the two lines of timber. 
Very soon I recollected Medium Lake beyond the river and I knew we were going just right. Wheelock then could see that we were going in the right direction, and we struck toward the timber, traveled by the compass, came to the river bottom after sunset, and the twilight gave us light enough to enable us to see the timber which we estimated to be from two to four miles distant. The snow was not hard enough to bear the oxen, and we left the eattle and sleigh with half a sack of flour for feed for them. The snow bearing us up, we traveled faster than at any previous time on the journey, and in fact, too fast, for after going farther than our estimate of four miles no timber was yet in sight, and we were nearly exhausted. We could often see lights, and hear all manner of sounds, but the others would insist that they were mere fancies. We found these frequent disappointments were weakening, and concluded that we would not talk of anything we saw or heard until we were sure it was real.

We traveled silently a mile or two more, as we estimated it, when Parmenter gave a start and looked keenly a little to the right of our course where I had just imagined I had seen a light. Immediately a shower of sparks as from a chimney was seen by all of us and we were strong again. In a few minutes we found a track in the snow where it was soft, plainly made since the blizzard had subsided, and by the aid of matches found that it was the track of one man going in our direction. The barking of a dog was distinctly heard, and in our joy we talked so loudly as to apparently awaken every dog in the settlement. We soon struck the river, and following down it on the ice we came to a trodden path where cattle went down to drink, thence by a good road we reached the foot of the bluff.

Still talking among ourselves we heard the voices of several persons, and stupidly hurrying up the hill, we heard the click of guns and the sharp ery, "Stop and answer or we will fire." Recognizing the voice, I called out, "Jim Hicky, is that you?" He instantly shouted to his companions, "It is the boys from the lake, Howe and Wheelock! call Thatcher!" In a moment Thatcher was before us and so haggard that we did not know 
him. He took my hand and tried to speak, but at first could not say a word. I soon recognized him and told him that there were two dead bodies at his house, both men, and I believed that there was no woman killed there.

The people of the Colony received us as from the dead, and nothing they could do for us was left undone, but we took no time for anything else till we learned what they knew of the massacre. This was quickly told. Morris Markham had gone from near Springfield in Minnesota to the lakes about fifteen miles from there, and had found nearly all of Gardner's family murdered. He went to Mattock's house and found it was burned and the people there and at Granger's were dead. The Indians were camped near the ashes of the burnt house, and he, in a dazed condition went almost into their eamp. He escaped as by a miracle and reached the river settlements before we left Doctor Bidwell's cabin when going to the lake. His interesting account of the danger and suffering has several times been published.

The men in the Colony, having heard that we were at Bidwell's, sent a man to warn us of the massacre, but a few miles from Bidwell's he learned we had already left. We were seen while taking our oxen and sleigh a few miles on the way, but we returned to the eabin that night to sleep there, and in the morning took our hand sleds, with blankets and utensils, to the teams. The people at Springfield had heard Markham's story, and sent two men to go on foot to Fort Ridgely for United States soldiers, and the settlers there were collecting in the best houses for defense. We learned also that another band of Indians was at the lakes in Emmet County, east of the river. A man had started from some point above the Colony to carry the news to Fort Dodge, but it was said that he was not strong enough to walk half way. There it was also rumored that the Indians had sent word to Springfield that they were going to kill the people in ten days, as they could not get away through the snow. We heard all these accounts and various rumors in less than an hour after reaching the river, and soon concluded what we would do. 
As soon as we had eaten supper, but late in the night, we went to bed and slept soundly until morning, an hour before sunrise, the time that we had asked them to awaken us. Parmenter was not able to sit or stand. Wheelock and Snyder were tired out, and my feet were so swollen that no boots were large enough, and I could not walk like a sober man. While eating breakfast we heard further news from men who came to learn what we had seen. One man had seen an Indian crossing the river above the Colony, and his trail went toward the camp on the Emmet county lake. An Indian had told the Springfield people that Henry, one of the messengers sent for help from Fort Ridgley, had been killed by the Indians from Spirit Lake. It was also rumored that the man who started for Fort Dodge had become erazy. We saw that the people at the Colony hoped some of our party would go to Fort Dodge for help, as they had not enough guns to arm the settlers, and we could be of little use. Markham was so badly frozen that he could not go, and they thought that his account of the massacre had made Thatcher crazy, and he, Thatcher, had been forcibly prevented from going to the lakes alone, while the Indians were known to be still there. But he appeared rational in the morning, and had concluded that his wife was a prisoner and his work was to rescue her. He talked but little, and it was plainly seen that an intense, but not strange thirst for vengeance controlled him.

Before noon my feet were lessening in size, and we concluded that Parmenter could remain and be of some use, even though disabled, and the others would start the next morning. We proposed to be ready at the first glimmer of daylight, and travel rapidly till the surface of the snow softened, then rest, and eat whether hungry or not. This being settled we began our sleep at sunset, and Parmenter waked us at ten o'clock in the evening for supper, and at one hour before daylight for breakfast. We began the trip ahead of time as there was a track for a few miles and we needed no light. The snow was hard enough to bear our weight till late in the afternoon when we took a rest and dinner, and then went to Evans' house before dark. 
The next morning daybreak found us on the way, and we traveled with good speed for a time, but the snow softened much earlier than the day before and we soon became tired. We hoped to reach Dakota before night, and from there, teams were traveling on the river ice to Fort Dodge. Mr. Carpenter was near the river above Evans', and hearing of us, sent word that we could get a team at Dakota. We did not arrive in sight of that town as soon as we expected, and fatigue from walking in the deep snow discouraged us. When nearly there, Snyder became so tired that he suddenly fell to the ground. We insisted upon waiting for him to rest, but he urged us to go on and send some one back from town to help him. After waiting for him nearly an hour and half, he still urging us to go on, we slowly proceeded. In a short time Wheelock and I sat down in the snow as though exhausted and Snyder soon got up and eame up to us. We rested a few moments more and went on.

When near Dakota, two men met us, and being told of our errand, went with us to the town. Here we met what seems the necessary sequence of an Indian outrage, that is, total stupid unbelief. The men who met us gave us the names of two or three persons who had teams, but it might be diffcult to hire one as there were many holes in the ice. They spoke also of a crazy man, while up the river, having been badly frightened by the reports he had heard. These men, however, did not appear to disbelieve us, and when we came to the hotel several eame to hear the rumors, and one of them soon found the owner of a good team, but he would not come to see us. Some of the doubters were willing to investigate the account, but a few were incorrigible. Snyder and Wheelock sharply answered some of the most insulting men, and were soon in a wordy conflict. While they were talking, some of the persons there said there was one man who would certainly let us have his team if he were only able to drive it, but he said that this man did not like to have any one else drive his team, and that he, himself, was lame, having recently broken his leg. 
One of the unbelievers gave me quite an examination for a minute or two, but in such a pompous manner that I was more amused than angry, and he was briefly. answered but not satisfactorily. He spoke of another crazy set trying to get up a seare, and began talking of the rumors some weeks previous and said there was no sense in them and none but a fool would believe them. I told him I heard of those rumors on my way to the lakes and knew what Major Williams and Lane and Ray thought about them, but still I went there. Then looking as pleasant as possible, I told him that I believed that he was now as much a fool as I was then, but was being eured in one minute, and if he would volunteer to go back with us, we would warrant him a quick and perfect cure. He only said that he was not fool enough to risk a team with us, but if any one was willing he did not care.

I had seen a man come into the room on erutehes, and as soon as this debate was ended, he asked if I wanted a team to go to Fort Dodge that night. I told him we were going if we had to do it on foot, but hoped we would get a team and asked if we could hire one of him. He asked my name and inquired if I knew a man in Jasper county named Reid. I then recognized him, and shaking hands, asked if I could have his mules. He said that no one should drive them but himself, but that he would take us there in an hour and a half, and that the team would be at the door in fifteen minutes. In less than that time he had us in a sleigh and before the end of an hour and a half we were in Fort Dodge.

Without any loss of time we found Major Williams who asked us how it was at the lakes. I told him all that he told us would probably happen had taken place, and about the people being murdered, and that help was badly needed in the vicinity. Major Williams went with us to a Methodist Church and spoke to the clergyman who was preaching, and without hesitation the minister told his congregation that the Spirit Lake settlement had been destroyed by the Indians, and immediate help was needed. He asked all able-bodied men to remain, and dismissed his congregation. A very short statement of the facts was made and volunteers called for. A 
man from Webster City said a company could be raised if one of our party would go with him. Wheelock went and they began recruiting about midnight. In the afternoon of the third day, more than one hundred men were enrolled, organized, provisioned, armed and equipped, and left Fort Dodge for the settlement. Without preparation, without question as to the authority of their officer, wihout any call from the officials of State or nation, these noble men took their guns and went out to perform a duty incumbent upon them as men, as citizens, and under a higher obligation to the Lord of hosts.

\section{A RISK THAT COST TWO LIVES.}

BY R. A. SMITH.

There are some incidents and circumstances connected with the Spirit Lake Expedition which, so far as I know, have never been printed, and which, while not as dramatic as those heretofore related, are equally as essential to a proper understanding of the events therein described. Mr. Duncombe, in his paper, ${ }^{1}$ says that information of the destruction of the settlements around Spirit Lake was brought to Fort Dodge by 0 . C. Howe, afterwards law professor in our State University and a companion, R. U. Wheelock; also another gentleman whose name he thinks was Parmenter.

The party above mentioned, together with a man by the name of Snyder who had visited the lakes the fall before and determined to settle there, had gone up on the west side of the river with supplies, arriving there on the night of the 16th of March. Before reaching the lakes they lost their course. Night coming on and with it a storm when they were three or four miles out, they were obliged to abandon their wagon and supplies. They took off their wagon box with its load, and left it at the edge of a slough, then pushed on with their team.

They reached the settlement about midnight, and found everything in confusion and apparently deserted. They went into camp until daylight, when they made such an investiga-

\footnotetext{
${ }^{1}$ ANNALS OF IOWA, 3 d ser., v. III, p. 495.
} 
Copyright of Annals of Iowa is the property of State of Iowa, by \& through the State Historical Society of Iowa and its content may not be copied or emailed to multiple sites or posted to a listserv without the copyright holder's express written permission. However, users may print, download, or email articles for individual use. 